\title{
Skema Handover pada Multi-kamera dengan Logika Fuzzy untuk Sistem Pemantauan Orang
}

\section{ACHMAD ILHAM IMANUDDIN¹, PRIMA KRISTALINA', BIMA SENA BAYU DEWANTARA ${ }^{2}$}

\author{
${ }^{1}$ Teknik Elektro, Politeknik Elektronika Negeri Surabaya, Indonesia \\ ${ }^{2}$ Teknik Informatika dan Komputer, Politeknik Elektronika Negeri Surabaya, Indonesia \\ Email : achmadilham07@gmail.com
}

Received 25 Juni 2020 | Revised 11 Juli 2020 | Accepted 13 Juli 2020

\begin{abstract}
ABSTRAK
Adanya berbagai peristiwa yang membahayakan di tempat keramaian menyebabkan diperlukannya sebuah sistem pemantauan aktifitas manusia di sekitarnya untuk pengawasan keamanan. Sistem multi-kamera sangat cocok digunakan untuk pemantauan target pada lingkungan area yang luas. Disaat target meninggalkan jangkauan area kamera menuju lainnya, proses pemantauan target harus tetap bekerja dan diserahkan ke kamera lainnya. Protokol serah terima target dapat berjalan jika terdapat komunikasi antar kamera yang tersedia. Penelitian ini menyajikan skema handover pada sistem multi-kamera dengan menerapkan pengambilan keputusan handover berbasis logika fuzzy. Dengan begitu, target akan selalu ditangani oleh kamera meskipun target bergerak menjauhinya. Berdasarkan hasil simulasi, skema handover ini mampu mereduksi total number of handover sebesar 20\% dibandingkan dengan metode AHCS (Active Handover Control Scheme). Selain itu, handover delay pada metode usulan memperoleh waktu 123.72us dan masih lebih lama dari AHCS.
\end{abstract}

Kata kunci: handover, multi-kamera, pemantauan orang, fuzzy logic

\begin{abstract}
The existence of various dangerous events in a crowded place causes the need of surveillance system to monitor the human activity continuously in a certain area. Multi-camera systems are used to monitor targets in large areas. When the target leaves the camera's range for another, the target monitoring process should continue to work and be left to other cameras. The target handover protocol may work if there is communication between the available cameras. This document presents a handover scheme in a multi-camera system by applying a fuzzy logic handover decision. Thus, the target will always be processed by the camera, even if the target is moving away from it. Based on the simulation results, this handover scheme is able to reduce the total number of handovers by $20 \%$ compared to the AHCS (Active Handover Control Scheme) method. In addition, the handover delay in the proposed method obtains $123.72 \mu$ s and is still longer than the AHCS.
\end{abstract}

Keywords: handover, multi-camera, human monitoring, fuzzy logic 


\section{PENDAHULUAN}

Saat ini, manfaat dari pelacakan orang dalam pengawasan sering kita jumpai di berbagai tempat, seperti perkotaan, perkantoran, bandara, dll. Hal tersebut dipakai untuk kebutuhan sistem keamaan dan pengenalan aktivitas sosial (Iguernaissi, Merad , Aziz, \& Drap, 2019). Penggunaan kamera tunggal tidak akan bekerja dengan maksimal apabila memiliki keterbatasan field of view. Selain itu, kita mungkin menjumpai kekurangan yang disebabkan oleh adanya oklusi pada lingkungan yang dapat menghambat proses pelacakan orang. Sehingga multi-kamera dibutuhkan. Selain memperluas pandangan kamera, penggunaan multikamera mampu meningkatkan pandangan dengan pemanfaatan kamera static melalui fitur perbesar (zoom) untuk mendapatkan tampilan multi-resolusi yang berbeda. Pengambilan gambar dari sudut pandang yang berbeda juga salah satu keuntungan yang dapat meningkatkan kadar informasi target yang dikumpulkan (Akyildiz, Melodia, \& Chowdhury, 2007).

Secara umum, skema pelacakan menggunakan kamera tunggal atau multi meliputi dua bagian sistem. Pertama, sistem deteksi dimana perlu adanya klasifikasi objek untuk mengenali objek pada suatu urutan gambar dan kedua adalah proses pelacakan posisi objek (Imanuddin, Kristalina, \& Dewantara, 2019) (Ardiyanto \& Miura, 2014) (Dewantara, Ardilla, \& Thoriqy, 2019) berdasarkan sistem deteksi. Tidak jarang pelacakan dengan kamera dikombinasikan dengan teknik handoffdalam pelacakan target yang spesifik. Kuo dan rekannya (Kuo, Huang, \& Nevatia, 2010) menyelidiki sistem yang dapat mengaitkan lintasan dari target bergerak melintasi kamera yang tidak tumpang tindih oleh model afinitas secara realtime. Peneliti di (Lin, Hwang, \& Huan, 2012) menawarkan Active Handover Control Scheme (AHCS) pada sistem multi-kamera dimana target akan dimonitoring secara mulus. Mereka menentukan kamera yang aktif berdasarkan dua peraturan, jarak terdekat dengan subkawasan dan hubungan spasial.

Studi dalam pelacakan orang menggunakan multi-kamera adalah masalah yang signifikan dengan jumlah peminat yang tidak sedikit. Tetapi, topik ini menjadi menantang karena perlu adanya koordinasi atau jaringan yang menghubungkan antara proses pelacakan tiap sensor yang digunakan. Informasi target pada tiap pandangan dikombinasi untuk mendapatkan lajur target yang valid (Kuo, Huang, \& Nevatia, 2010). Saat target bergerak keluar area pandangan kamera, membutuhkan mekanisme yang baik untuk mengatasi target tersebut. Dengan kata lain, jaringan antar sensor tertanam berperan penting dalam mengatur komunikasi agar pelacakan target berjalan dengan baik ( $\mathbf{L i}, \mathbf{K i m}, \mathbf{H a n}, \mathbf{\&}$ Lee, 2019). Perubahan pergerakan target yang fleksibel memungkinkan target bergerak dari pandangan satu ke lainnya. Sehingga proses pelacakan orang diserahterimakan ke sensor tertanam lainnya. Ketika orang berpindah dari satu area pandangan kamera ke area lainnya, perpindahan orang tersebut dapat dilacak secara terus-menerus.

Konsep ini sama halnya dengan sistem komunikasi seluler dimana mampu memastikan mobile user terhubung dengan server saat berpindah antar lokasi. Mekanisme ini sering disebut sebagai proses handover yang mentransfer panggilan yang sedang berlangsung ke antar sel ketika pengguna bergerak melalui jaringan selular (Lee, Sriram, Kim, Kim , \& Golmie, 2009) (Sun \& Qian, 2016). Jarak antara mobile userdengan cel/biasanya digunakan sebagai parameter yang menentukan proses handover dijalankan atau tidak. Jika semakin jauh jarak antar entitas (mobile user dan sel), sistem akan mempertimbangkan untuk dilakukannya handover. Jaringan target akan dipilih bergantung pada algoritma pengambilan keputusan yang digunakan. Apabila prinsip handover ini diterapkan pada pemantauan orang menggunakan kamera memungkinkan orang dapat dilacak walaupun sudah keluar dari area pandangan kamera. 
Dalam jaringan nirkabel, banyak sekali algoritma handover untuk memilih jaringan terbaik diantara jaringan yang tersedia. Terdapat beberapa parameter QoS yang mempengaruhi pemilihan jaringan dalam mengambil keputusan (Subramani \& Kumaravelu, 2019). Multiple Attribute Decision Making (MADM) merupakan metode pemilihan opsi terbaik dari alternatif opsi yang tersedia berdasarkan beberapa kriteria tertentu. Namun, jika jumlah parameter yang digunakan meningkat, komputasi algoritma MADM menjadi kompleks. Logika Fuzzy merupakan salah satu algoritma berbasis artificial intelligence yang dapat membuat keputusan dari kemungkinan opsi yang ada. Penulis (Tillapart, Thumthawatworn, Viriyaphol, \& Santiprabhob, 2015) mengusulkan desain sistem keputusan handover berbasis fuzzy baru untuk mengurangi kompleksitas mesin fuzzy tanpa mengurangi kinerjanya. Pada (Liu, Kwong, Zhang, \& Li, 2019) mengembangkan algoritma handover berbasis fuzzyTOPSIS untuk mengurangi number of handover dan ping-pong effect. Dengan metodenya, mereka mampu meminimalkan rasio ping-pong dan total handover yang berlebihan.

Kami mengusulkan sebuah skema komunikasi kamera-ke-kamera dengan menerapkan mekanisme handover pada sistem pemantauan orang tunggal. Penggunaan handover mengadopsi cara kerja komunikasi seluler antara mobile user dengan cell, dimana mobile user akan dialihkan ke cel/lain jika posisinya menjauhi cel/sebelumnya. Dengan begitu, saat kamera asal menangani target dimana posisinya jauh dari pandangannya, sistem akan mengevaluasi parameter untuk menjalankan proses handover. Selain itu, kami menawarkan algoritma pengambilan keputusan menggunakan logika fuzzy dengan parameter masukan yang mendukung proses pemantauan orang menggunakan kamera. Algoritma ini yang akan menentukan kamera mana yang akan menangani pemantauan target.

\section{METODE PENELITIAN}

\subsection{Skema handover pada Sistem Multi-Kamera}

Dalam sistem komunikasi seluler, terdapat entitas yang berpengaruh penting saat melangsungkan proses handover, yakni mobile user, current atau target cell, dan service center. Entitas mobile user biasanya dilengkapi dengan transceiver dan diprogram untuk mengirim dan menerima sinyal untuk berkomunikasi antar mobile user lainnya. Mobile user mengakses layanan percakapan melalui cel/ terdekatnya untuk melakukan komunikasi. Entitas cell akan tetap menangani mobile user dengan jangkauan area yang luas. Kondisi ini memungkinkan mobile user bergerak secara meluas sehingga ada saatnya cell tidak dapat menjangkaunya. Keadaan ini mengakibatkan mobile user tidak dapat melakukan komunikasi karena tidak adanya koneksi dengan cel/ terdekatnya. Hal ini disiasati dengan mendirikan cell baru untuk menangani tempat kosong dimana cel/ sebelumnya tidak dapat menjangkau area tersebut. Dengan begitu, layanan komunikasi antara mobile user dengan cell sebelumnya dialihkan ke cel/ baru atau cel/ target yang mampu melanjutkan layanan tersebut (Tillapart, Thumthawatworn, Viriyaphol, \& Santiprabhob, 2015). Penentuan cell target pun ditangani oleh entitas service center yang mengatur dan memilih cel/ target sebagai penyedia layanan mobile user. Disaat mobile user berpindah tempat menjauhi cell sebelumnya, maka layanan komunikasi tidak akan terputus karena layanan akan diserahkan ke cel/ target yang dekat dengannya.

Skema handover pada sistem multi-kamera ini menerapkan prinsip handover pada sistem komunikasi seluler. Sama halnya pada komunikasi seluler, tujuan adanya skema handover ini untuk melakukan pemantauan orang melalui kamera. Jika orang tersebut menjauhi kamera pemantau, maka proses pemantauan akan tidak bisa dilakukan. Konsep ini dapat mengadopsi prinsip handover yang mampu menangani mobile user jika cel/ tidak mampu menjangkaunya. Terdapat tiga entitas utama dalam menerapkan skema hanover ini, yakni Human Target (HT), Camera Node (CN), dan Camera Node Service center (CNSC). Pada skema ini, HT berperan seperti mobile user, sedangkan CN dan CNSC masing-masing berperan seperti cell dan Service center. Peran HT disini hanya melakukan bergerak, berpindah posisi dari lokasi satu ke lokasi 
lainnya. Untuk menerapkan proses pemantauan, keberadaan HT selalu diawasi oleh CN. Jika HT berada pada jarak yang jauh, CN tidak mampu untuk menjangkau dan tidak dapat mengidentifikasinya. Kamera sendiri memiliki batasan penglihatan yang mampu dijangkaunya. Sehingga, CN selanjutnya atau CN target akan dipilih untuk melanjutkan proses pemantauan dari sudut pandang yang berbeda. Pemilihan CN target akan ditentukan oleh CNSC berdasarkan parameter tertentu. Keputusan yang akan diambil oleh CNSC akan berpengaruh dalam proses pemantauan HT. Perpindahan proses pemantauan ini mengakibatkan HT dipindah-tangankan ke CN lainnya. Agar skema handover ini bekerja, CN dan CNSC saling terhubung dengan suatu jaringan nirkabel agar parameter pendukung dapat dikirim ke CNSC dan dikembalikan ke CN target untuk melakukan pemantauan. Gambar 1 merupakan komunikasi antar CN dengan CNSC dimana seluruh CN terhubung dengan CNSC melalui Wireless Local Area Network (WLAN) yang tersedia pada ruang observasi.

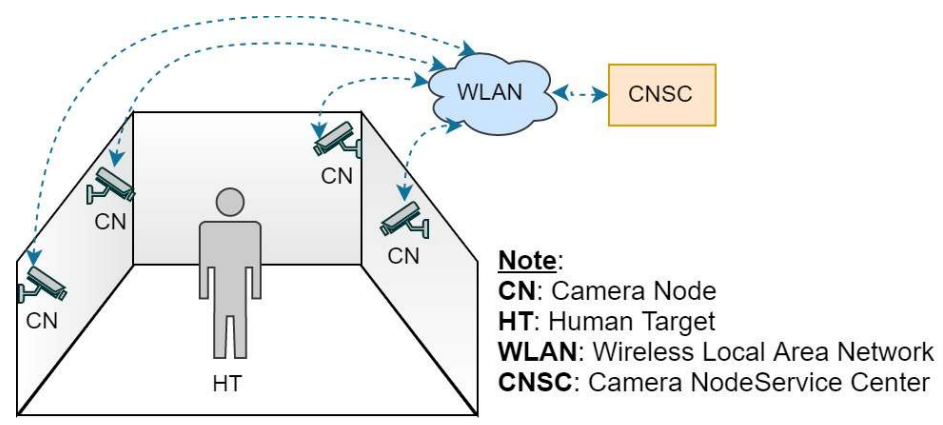

Gambar 1. Komunikasi Antar Node Kamera Dengan Service Center

\subsection{Prosedur Handover pada Sistem Multi-Kamera}

Pada sistem komunikasi seluler memiliki 3 tahapan dalam melakukan proses handover, yang meliputi handover decision, pemilihan cell target, dan handover completion. Tahap handover decision, mobile user akan menerima parameter pendukung seperti kuat sinyal untuk dilakukan proses pengambilan keputusan. Kuat sinyal menjadi dasar untuk mengetahui keberadaan mobile user terhadap cel/ terdekatnya. Jika sinyal melemah, maka dapat dikatakan mobile user berada jauh dari cel/ sebelumnya. Untuk itu, pemilihan cel/target dilakukan untuk memilih cell yang akan bertanggungjawab menangani mobile user. Service centerakan mempertimbangkan parameter pendukung untuk memilih cel/target dari cel/yang tersedia. Setelah ditentukan, cell target akan melanjutkan proses komunikasi dengan mobile user.

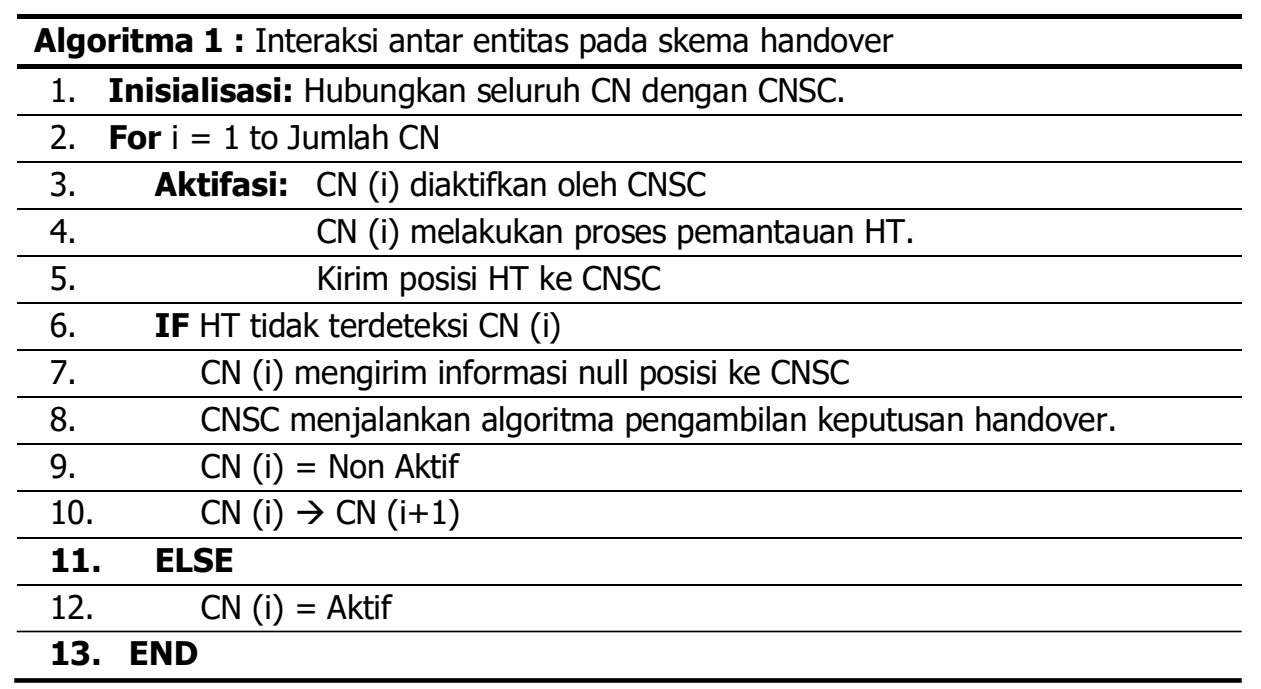


Pada skema handover ini menerapkan 3 tahapan juga, yakni initial handover, CN selection, dan handover execution. Proses pemantauan HT dimulai saat CN melakukan identifikasi HT melalui kamera dan diukur posisinya terhadap CN. Dalam proses mengukur posisi HT, CN akan mengirimkan posisi ke CNSC untuk dilakukan proses pengambilan keputusan. Jika dinyatakan bahwa HT berada diluar jangkauan CN, CNSC akan menyerahkan CN target untuk melanjutkan proses pemantauan. Algoritma 1 merupakan alur lengkap mengenai cara kerja skema handover ini bekerja. Terdapat tiga parameter yang digunakan sebagai masukan pada sistem pengambilan keputusan pada tahap initial handover, yakni jarak, orientasi, dan arah gerak HT. Ketiga parameter ini diproses untuk menentukan CN target. Tahap CN selection ini bekerja dengan menentukan CN target berdasarkan parameter tersebut menggunakan logika fuzzy. Jika keluaran dari logika fuzzy menyatakan bahwa tidak perlu melakukan handover, maka CN sebelumnya tetap melanjutkan proses pemantauan. Jika dinyatakan perlu melakukan handover, maka tahap handover execution berjalan dimana CNSC akan mengaktifkan CN target sehingga proses pemantauan dapat berlanjut secara sekuensial.

\subsection{Pengambilan Keputusan Handover Berbasis Fuzzy Logic}

Lotfi A. Zadeh (Bai \& Wang, 2006) (Jang, Sun, \& Mizutani, 1997) memperkenalkan logika fuzzy untuk mengatasi permasalahan dengan pernyataan yang tidak sepenuhnya benar atau salah. Logika fuzzy dapat menghasilkan pernyataan kabur diantara sebuah pernyataan yang valid sehingga mampu mengontrol sebuah kondisi tertentu. Pada komunikasi seluler, logika fuzzy sering digunakan untuk memutuskan sebuah kondisi dalam suatu sistem handover dalam pengambilan keputusan. Dengan Multiple Attribute Decision Making (MADM) menggunakan logika fuzzy berguna untuk mengambil sebuah keputusan yang tepat dan berjalan secara realtime. Terdapat beberapa jenis sistem inferensi pada logika fuzzy seperti Mamdani, SugenoTsukamoto, tetapi dalam skema ini menerapkan metode Sugeno-Tsukamoto (Naeem, Ngah, \& Hashim, 2018) untuk menghasilkan kemungkinan handover yang akan dijalankan sistem.

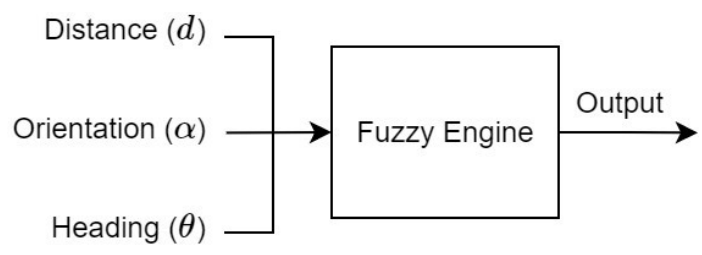

\section{Gambar 2. Mesin Fuzzy pada Pengambilan Keputusan Handover}

Gambar 2 menunjukkan blok diagram sistem pengambilan keputusan menggunakan logika fuzzy. Dalam skema handover ini terdapat 3 parameter yang akan menjadi input dalam mesin fuzzy, 1) jarak antara HT dengan $\mathrm{CN}(d), 2)$ orientasi HT terhadap $\mathrm{CN}(\alpha)$, dan 3) arah hadap HT terhadap perpindahan waktu $(\theta)$. Keluaran dari mesin fuzzy (output) berupa probabilitas handover dari $\mathrm{CN}$ target. Ketiga parameter input akan mempengaruhi hasil keluaran dimana berfungsi untuk menentukan CN target yang akan aktif menangani HT.

\subsubsection{Variabel masukan pada mesin fuzzy}

Ketiga parameter masukan pada mesin fuzzy berupa data skalar dengan variasi rentang nilai yang berbeda-beda. Untuk mengetahui probabilitas handover dari CN target, ketiga parameter harus dikelompokkan dan diubah menjadi nilai linguistik untuk setiap nilai terukur dari parameter masukan. Perubahan nilai skalar menjadi nilai linguistik disebut proses fuzzifikasi.

Parameter pertama adalah distance $(d)$, maksudnya adalah jarak antara titik HT berdiri terhadap titik CN, ilustrasinya ditampilkan pada Gambar 3(a). Nilai distance ini diberikan oleh Persamaan (1). 


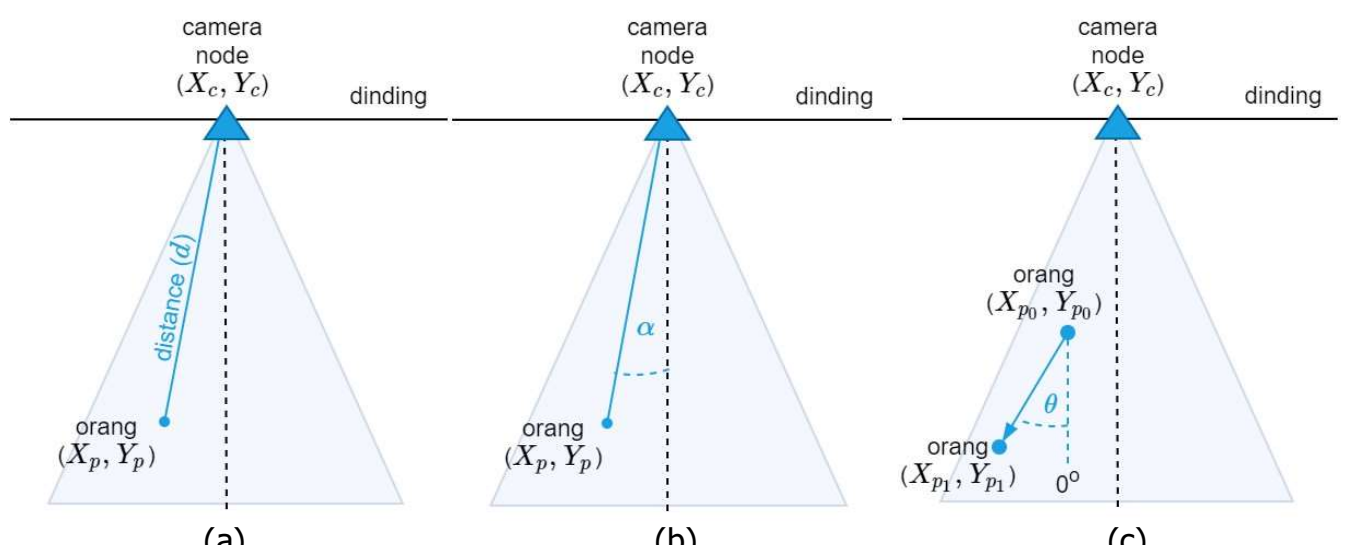

(a)

(b)

(c)

Gambar 3. Analogi Cara Mengambil Data (a) Distance dan (b) Orientation antara HT dengan CN serta Data (c) Heading terhadap Perubahan Waktu

$$
d=\sqrt{\left(X_{p}-X_{c}\right)^{2}-\left(Y_{p}-Y_{c}\right)^{2}}
$$

Dimana $d$ adalah jarak antara HT dan $\mathrm{CN}$ dalam satuan meter, lalu $\left(X_{c}, Y_{c}\right)$ merupakan titik koordinat $\mathrm{CN}$ terhadap ruang observasi, sedangkan $\left(X_{p}, Y_{p}\right)$ adalah estimasi koordinat HT terhadap bidang cakupan kamera. Selanjutnya adalah orientation $(\alpha)$ yang menunjukkan keberadaan orientasi HT terhadap CN. Gambar 3(b) menunjukkan ilustrasi pengambilan parameter orientation. Nilai orientation dapat dihitung menggunakan Persamaan (2).

$$
\alpha=\tan ^{-1} \frac{\left(X_{p}-X_{c}\right)}{\left(Y_{p}-Y_{c}\right)}
$$

Dimana $\alpha$ merupakan orientasi HT terhadap CN dalam satuan derajat. Parameter terakhir adalah heading $(\theta)$ yang menunjukkan arah gerak $\mathrm{HT}$ terhadap perubahan waktu $(\Delta t)$. Gambar 3(c) menunjukkan ilustrasi pengambilan parameter heading. Nilai heading ini diberikan oleh Persamaan (3) dan (4).

$$
\begin{gathered}
\theta_{T}=\tan ^{-1} \frac{\left(X_{p_{1}}-X_{p_{0}}\right)}{\left(Y_{p_{1}}-Y_{p_{0}}\right)} \\
\theta=\theta_{T}+K
\end{gathered}
$$

Dimana $\theta_{T}$ adalah arah gerak HT sementara terhadap perubahan waktu dalam satuan derajat, lalu $\left(X_{p 0}, Y_{p 0}\right)$ adalah posisi HT pada gambar saat ini, sedangkan untuk $\left(X_{p 1}, Y_{p 1}\right)$ adalah posisi HT pada gambar berikutnya. Kemudian $K$ merupakan konstanta yang berubah-ubah bergantung pada keberadaan nilai $\theta_{T}$ di dalam kuadran dan $\theta$ adalah nilai heading akhir terhadap perubahan waktu dalam satuan derajat.

\subsubsection{Struktur fungsi keanggotaan}

Fungsi keanggotaan dalam metode fuzzymenunjukkan kurva pemetaan titik-titik masukan data kedalam nilai keanggotaan yang memiliki nilai antara 0 hingga 1 . Pada skema ini memakai fungsi keanggotaan triangular untuk melakukan proses blok fuzzifikasi.

Parameter masukkan distance dipartisi dalam semesta wacana antara [0m-5m] menjadi 5 fungsi keanggotaan triangular: very small (VS), small (S), medium (M), big (B) dan very big (VB). 
Parameter orientation dipartisi dalam semesta wacana antara $\left[0^{\circ}-17^{\circ}\right]$ menjadi 7 fungsi keanggotaan triangular: negative big (NB), negative medium (NM), negative small (NS), zero $(\mathrm{Z})$, positive small (PS), positive medium (PM), dan positive big (PB).

Untuk parameter heading dibagi dalam semesta wacana antara $\left[-180^{\circ}-180^{\circ}\right]$ menjadi 9 fungsi keanggotaan triangular: negative front $(\mathrm{NF})$, front left $(\mathrm{FL})$, left $(\mathrm{L})$, back left $(\mathrm{BL})$, back $(\mathrm{B})$, back right (BR), right (R), front right (FR), dan positive front (PF). Seluruh ilustrasi fungsi keanggotaan masukan dapat dilihat pada Gambar 4.

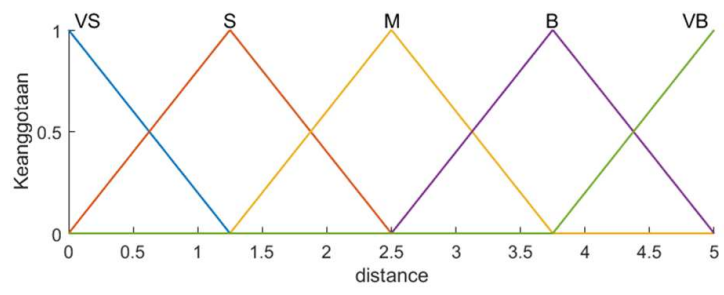

(a)

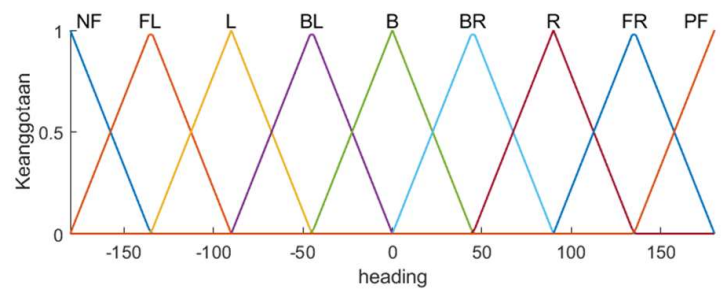

(c)

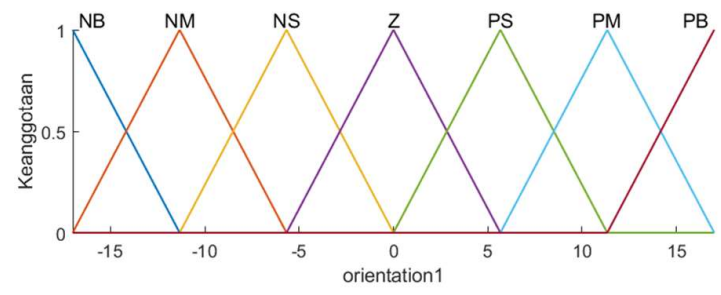

(b)

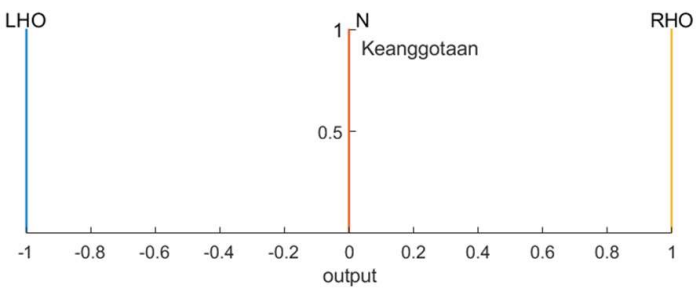

(d)

Gambar 4. Fungsi Keanggotaan Masukan untuk Parameter (a) Distance, (b) Orientation, (c) Heading serta (d) Output

Semesta wacana pada tiap parameter disesuaikan pada hasil estimasi dari sistem pemantauan serta dilakukan tria/dan error. Selain itu penggunaan kamera juga mempengaruhi nilai semesta wacana sebab field of view (FoV) menjadi batasan penglihatan kamera.

\subsubsection{Struktur aturan fuzzy}

Berdasarkan fungsi keanggotaan, parameter input distance memiliki 5, orientation memiliki 7, dan heading memiliki 9 keanggotaan. Karenanya, mesin fuzzy memiliki 315 kombinasi aturan. Secara garis bersar kombinasi aturan memiliki 3 tipe keluaran, yakni none $(\mathrm{N})$, left handoff (LHO), dan right handoff (RHO). Tipe none memiliki makna bahwa HT tidak akan dilakukan handover karena HT masih berada pada jangkauan CN saat ini. Untuk tipe LHO bermakna HT akan diteruskan ke CN target sebelah kiri dari CN saat ini. Kondisi ini terjadi karena HT bergerak ke arah kiri membelakangi kamera. Jika HT bergerak sebaliknya (ke kanan) maka tergolong tipe RHO.

\section{HASIL DAN PEMBAHASAN}

\subsection{Skenario simulasi pada skema handover}

Dalam menganalisa skema handover ini dilakukan sebuah simulasi dimana HT bergerak pada area observasi dengan tersedianya kamera pada sudut ruangan. Simulasi ini ditanamkan pada bahasa pemrograman $\mathrm{C}++$ untuk menghasilkan kinerja skema handover. Pada simulasinya dibuat sebuah area observasi dengan luasan ruang 8x8 meter persegi, ditunjukkan pada Gambar 5. Penempatan node kamera diletakkan pada sisi dan sudut ruangan dimana ditampilkan dengan segitiga biru, dan area jangkauan kamera ditunjukkan dengan segitiga berwarna transparan. Jumlah node kamera yang digunakan adalah empat buah, dan diletakkan 
secara tersebar untuk memudahkan HT bergerak dan dijangkau oleh node kamera yang dilaluinya.

Dalam simulasi ini, HT akan bergerak mula-mula dari titik start ke titik akhir. Terdapat 2 jenis lintasan yang dilalui HT untuk mencapat titik terakhir. Lintasan pertama HT akan bergerak dari area 1 menuju ke area 4 melalui area 2 dan 3. HT tetap bergerak menuju area 4 tanpa adanya kembali lagi ke area sebelumnya, sehingga area yang dilalui HT dari area 1-2-3-4. Kondisi ini mengakibatkan perubahan area yang dilaluinya sejumlah 3 area. Lintasan kedua HT akan bergerak dari area 1 menuju ke area 4 tetapi pergerakannya berputar-putar, sehingga HT bergerak kembali ke area sebelumnya. Pada lintasan kedua, HT melalui beberapa area, yakni area 1-2-1-2-3-4. Berdasarkan area yang dilalui HT pada lintasan kedua, jumlah perubahan areanya adalah 5 area. Secara jelasnya, Gambar 6 (a) untuk pergerakan lintasan pertama, sedangkan (b) untuk lintasan kedua.

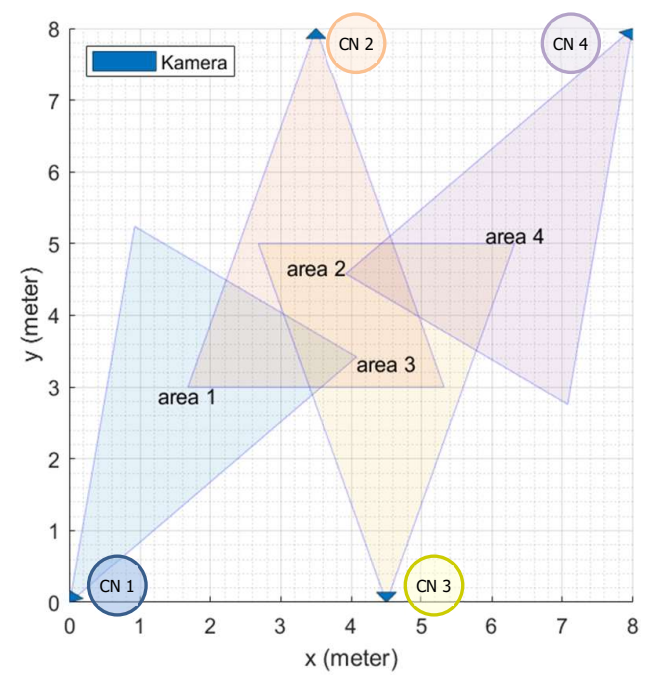

Gambar 5. Kondisi Ruangan Observasi dengan Luasan 8x8 Meter Persegi

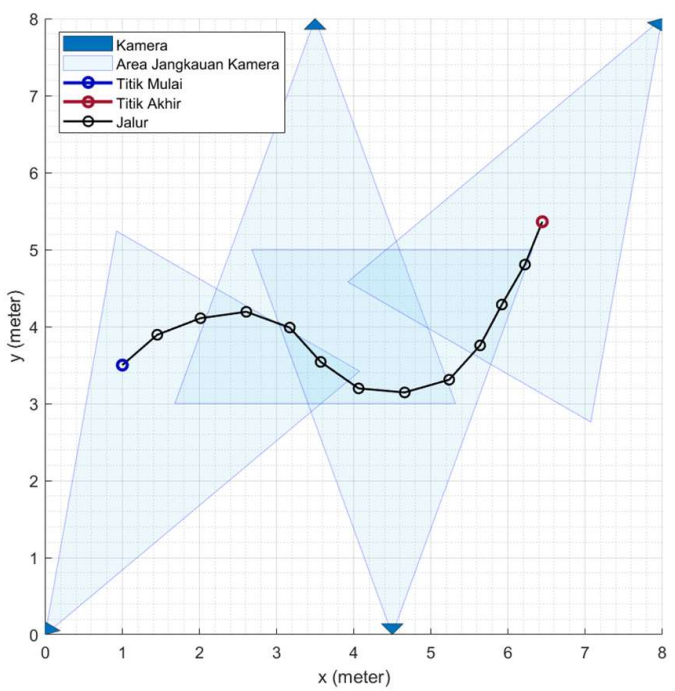

(a)

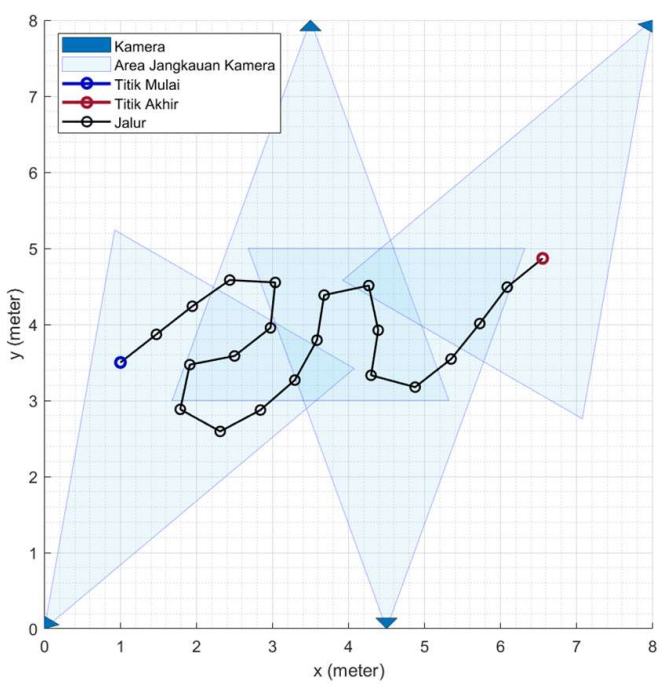

(b)

Gambar 6. Lintasan yang dilalui HT pada Area Observasi, dimana (a) HT Bergerak tanpa Kembali ke Area Sebelumnya, dan (b) HT Kembali ke Area Sebelumnya 


\subsection{Analisa Skema Handover}

Pengambilan keputusan dalam skema handover ditentukan berdasarkan parameter yang digunakan. Jika kombinasi parameter tersebut menghasilkan kondisi pernyataan "handover", maka proses penanganan HT akan diserahkan ke CN lain. Kombinasi parameter dipengaruhi oleh perubahan posisi HT yang bergerak melintasi area observasi. Untuk menguji kinerja metode usulan, kami akan membandingkan metode lain dengan nama Active Handover Control Scheme (AHCS) (Lin, Hwang, \& Huan, 2012), dimana kamera target ditentukan dengan jarak antara HT dengan kamera selanjutnya. Tiap metode akan menjalankan kedua lintasan yang telah disediakan (dapat dilihat pada Gambar 6).

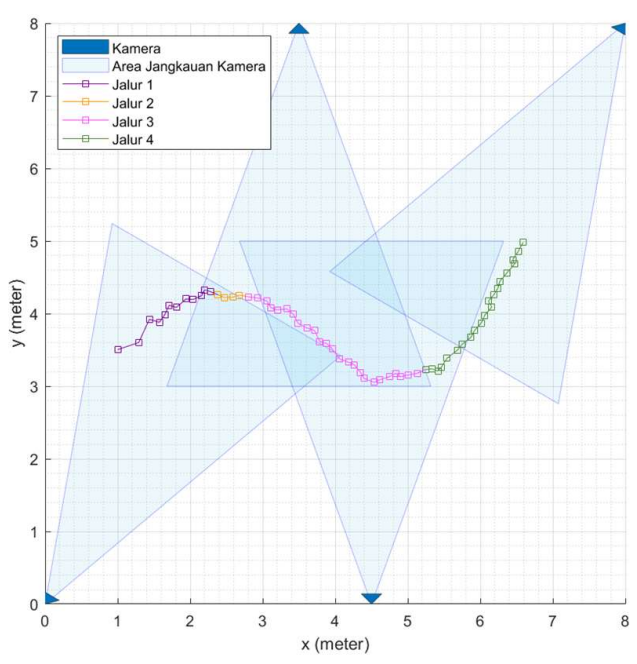

(a)

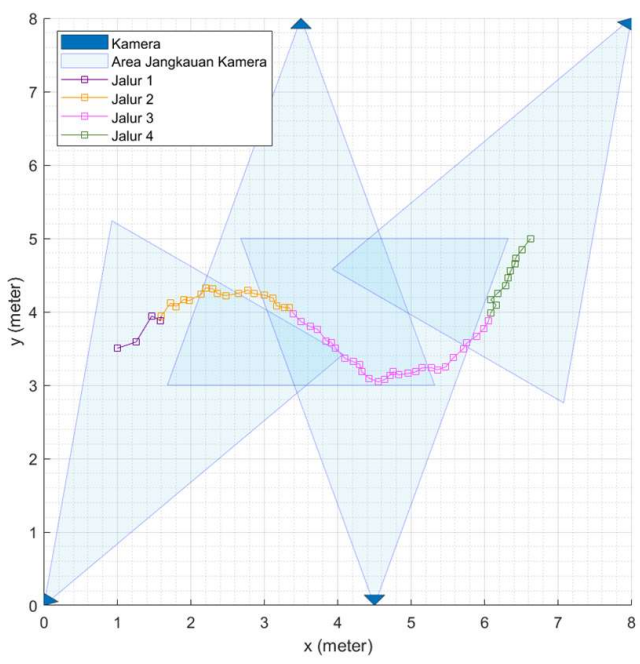

(c)

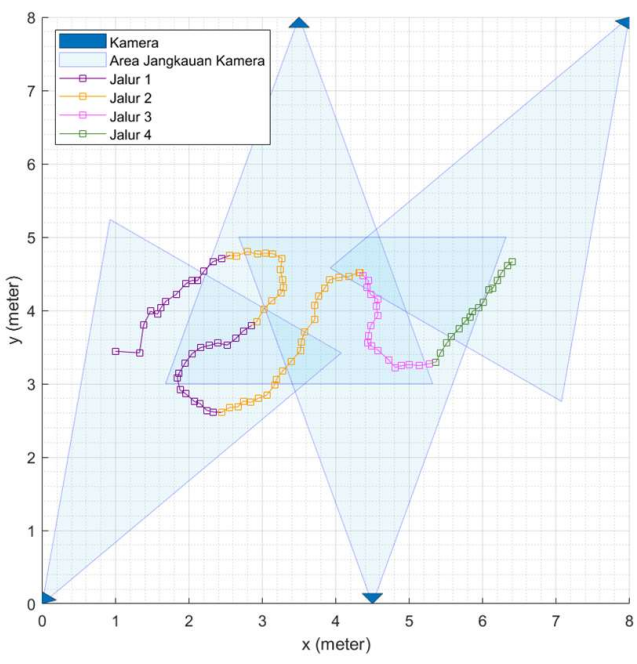

(b)

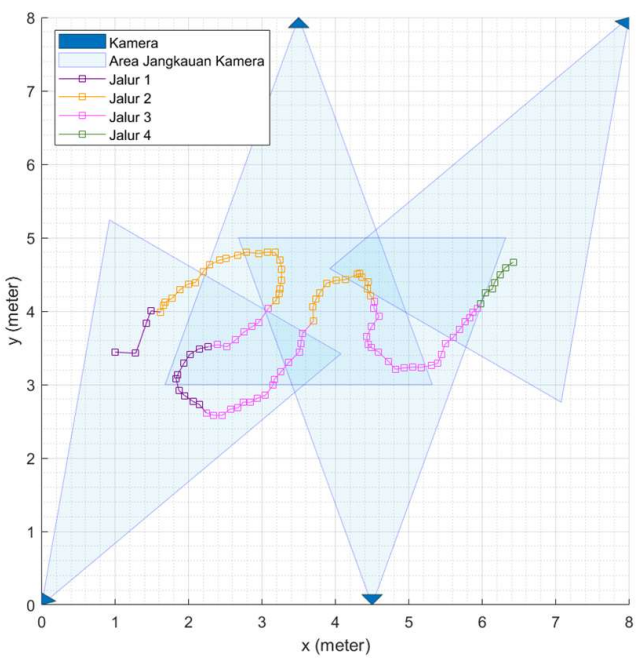

(d)

Gambar 7. Hasil Skema Handover HT yang ditangani oleh Tiap CN, dimana (a) dan (b) Menerapkan Metode Usulan pada Kedua Lintasan, sedangkan (c) dan (d) Menerapkan AHCS pada Kedua Lintasan

Setelah skema handover diterapkan pada kedua jalur, hasil handover HT ditunjukkan pada Gambar 7. Seperti yang telah dijelaskan sebelumnya, HT mulai bergerak dari area 1 menuju ke area 4. Pada hasil handover HT ditampilkan jalur dengan warna yang berbeda-beda. Warna tersebut merepresentasikan penanganan $\mathrm{HT}$ terhadap $\mathrm{CN}$ yang bersangkutan. Warna coklat 
(jalur 1) menunjukkan HT berada pada penanganan $\mathrm{CN} 1$, warna kuning (jalur 2) ditangani oleh CN2, warna merah muda (jalur 3) untuk CN 3 dan CN 4 menagani HT yang berada pada titik berwarna hijau (jalur 4). Maksud dari perubahan warna tersebut supaya mengetahui perubahan penanganan $\mathrm{HT}$ terhadap $\mathrm{CN}$ yang terkait serta berapa kali perubahan handover dilakukan dalam satu lintasan.

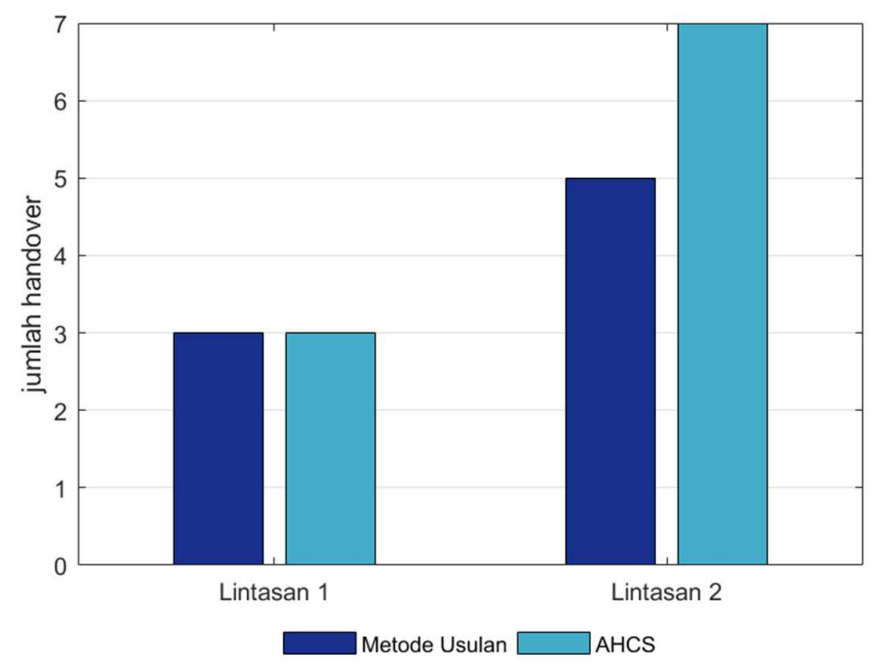

Gambar 8. Jumlah Handover terhadap Keseluruhan Skenario

Salah satu metrik kinerja dalam sistem handover untuk mengukur pencapaian sebuah metode adalah jumlah handover (number of handover). Metrik ini mengukur total sebuah sistem menjalankan proses handover pada suatu lintasan. Jika dalam sebuah skema handover, proses handoverdalam jumlah besar sangat tidak disarankan karena dapat menyebabkan pemborosan sumber daya jaringan. Dengan meminimalkan proses tersebut mampu mempertimbangkan beban handover dari suatu jaringan yang terhubung. Pada Gambar 8 memperlihatkan total number of handover pada tiap metode di setiap skenario pengujian. Berdasarkan lintasan yang disusun, pada lintasan pertama HT berjalan dari area 1 menuju area 4 dengan berpindah area sebanyak tiga kali, dari area 1 ke area 2, dilanjutkan dengan area 2 ke area 3, dan terakhir area 3 ke area 4. Menurut hasil yang didapat, metode usulan dan AHCS mampu mengatasi perpindahan HT dengan benar, dimana keduanya menghasilkan nilai yang sama yaitu tiga kali. Namun, pada lintasan kedua didapatkan nilai yang berbeda. Menurut perubahan gerak HT, pada lintasan kedua berpindah area sebanyak lima kali. Hal ini ditunjukkan dengan perubahan area dari area 1 ke area 2, lalu HT kembali ke area 1, berlanjut ke area 2, ke area 3 dan terakhir ke area 4. Metode usulan mampu menangani perpindahan HT melintasi beberapa node kamera. Daripada AHCS, metode usulan lebih unggul 20\% dalam mengatasi transisi HT dari area $1 \mathrm{ke}$ area 4. Pengambilan keputusan pada metode usulan mampu mengurangi jumlah number of handover.

Dalam menentukan keputusan handover, sistem ini memerlukan perhitungan yang sistematis untuk mendapatkan keluaran yang tepat. Jika komputasi dalam pengambilan keputusan memakan waktu yang lama maka penanganan HT juga akan terlambat. Handover delay merupakan salat satu metrik kinerja untuk melihat waktu komputasi tiap metode dalam melakukan prosesnya. Metrik ini akan mulai dijalankan saat inisialisasi parameter didapatkan dan berhenti saat pengambilan keputusan handover didapatkan. Metrik handover delay dikatakan baik saat waktu komputasi dalam menentukan keputusan handover lebih cepat. Gambar 9 menunjukkan grafik handover delay terhadap perubahan iterasi pada tiap metode. Berdasarkan hasil tersebut, metode usulan memiliki nilai rerata delay sebesar $123.72 \mu \mathrm{s}$,

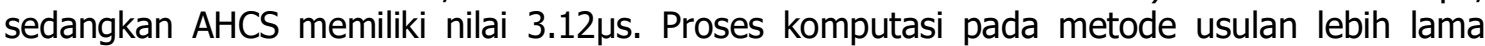
dibandingkan dengan dengan proses AHCS. Hal ini terjadi dikarenakan metode usulan memiliki 
aturan sebanyak 315 aturan dengan 3 parameter input. Dengan kondisi tersebut perlu adanya pencocokan aturan serta komputasi matematis yang banyak sehingga membutuhkan waktu yang lebih lama. Berbeda dengan AHCS yang hanya mengandalkan jarak minimum tiap CN terdekat yang mengakibatkan komputasi lebih cepat.

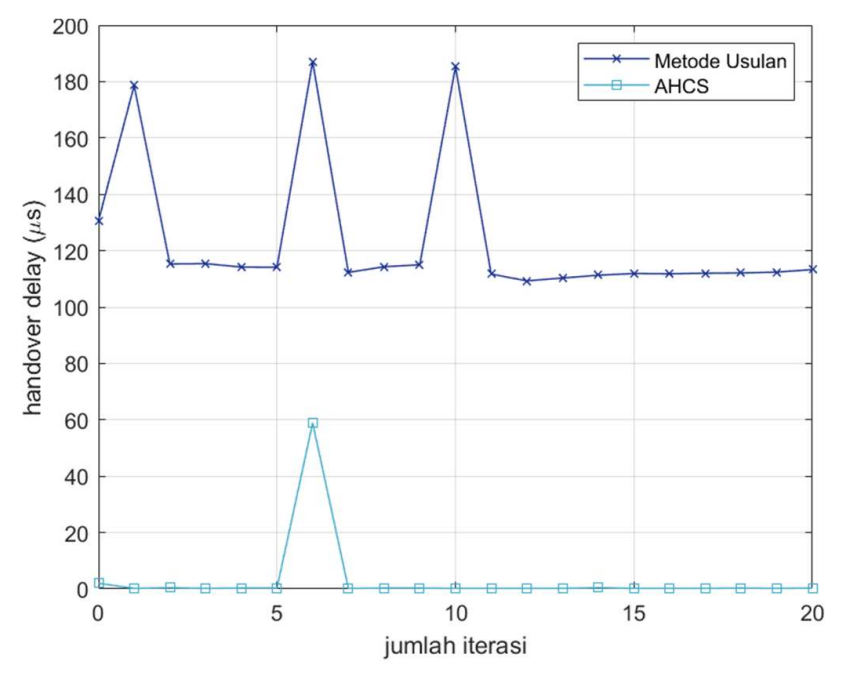

Gambar 9. Handover Delay terhadap Perubahan Iterasi

\section{KESIMPULAN}

Pada penelitian ini, kami mengenalkan sebuah skema handover pada sistem multi-kamera untuk keperluan pemantauan orang. Skema handover ini mengadopsi prinsip handover pada sistem komunikasi seluler dengan menerapkan Multiple Attribute Decision Making (MADM). Sistem MADM menggunakan logika fuzzy dengan tiga parameter yakni jarak, orientasi, dan arah gerak orang. Pengambilan keputusan berbasis logika fuzzy dalam skema handover disajikan untuk menentukan kamera mana yang akan menangani pemantauan target. Untuk tujuan perbandingan dan evaluasi, kami menyiapkan kondisi ruangan dimana memiliki area tumpang tindih antar kamera. Secara simulasi, skema handover dijalankan dengan dua jenis lintasan yang berbeda. Metode usulan mampu menangani target $20 \%$ lebih baik daripada menggunakan Active Handover Controll Scheme (AHCS). Namun, dari segi waktu komputasi metode usulan kami memiliki waktu $123.72 \mu$ s dan masih lebih lama dibandingkan AHCS.

Sebagai pekerjaan selanjutnya, skema handover ini akan dimplementasikan secara real-time dengan perangkat node yang memadai untuk proses pemantauan. Sebagai tambahan, metode pengambilan keputukan akan menerapkan lebih banyak parameter QoS seperti kegagalan handover, latensi handover, dll, untuk mengukur kinerja metode.

\section{UCAPAN TERIMA KASIH}

Sebagian dari pekerjaan penelitian ini didanai oleh Penelitian Kompetensi Nasional dengan skema Penelitian Thesis Magister dari Direktorat Riset dan Pengabdian Masyarakat, Kementerian Riset dan Teknologi Republik Indonesia dengan nomer kontrak 010/SP2H/LT/DRPM/2020. 


\section{DAFTAR RUJUKAN}

Akyildiz, I. F., Melodia, T., \& Chowdhury, K. R. (2007). A survey on wireless multimedia sensor networks. Computer Networks, 51(4), 921-960.

Ardiyanto, I., \& Miura, J. (2014). Partial least squares-based human upper body orientation estimation with combined detection and tracking. Image and Vision Computing, 32(11), 904-915.

Bai, Y., \& Wang, D. (2006). Fundamentals of fuzzy logic control-fuzzy sets, fuzzy rules and defuzzifications. In Advanced Fuzzy Logic Technologies in Industrial Applications (pp. 17-36). London: Springer.

Dewantara, B., Ardilla, F., \& Thoriqy, A. (2019). Implementation of Depth-HOG based Human Upper Body Detection On A Mini PC Using A Low Cost Stereo Camera. 2019 International Conference of Artificial Intelligence and Information Technology (ICAIIT). Yogyakarta, Indonesia: IEEE.

Iguernaissi, R., Merad , D., Aziz, K., \& Drap, P. (2019). People tracking in multi-camera systems: a review. Multimedia Tools and Applications, 78(8), 10773-10793.

Imanuddin, A., Kristalina, P., \& Dewantara, B. (2019). A Moving Human Detection and Tracking using Combination of HOG and Color Histogram. 2019 International Electronics Symposium (IES).

Jang, J., Sun, C.-T., \& Mizutani, E. (1997). Neuro-Fuzzy and Soft Computing: A Computational Approach to Learning and Machine Intelligence. IEEE Transactions on automatic control, 42(10), 1482-1484.

Kuo, C.-H., Huang, C., \& Nevatia, R. (2010). Inter-camera Association of Multi-target Tracks by On-Line Learned Appearance Affinity Models. European Conference on Computer Vision (pp. 383-396). Berlin, Heidelberg: Springer.

Lee, S., Sriram, K., Kim, K., Kim , Y., \& Golmie, N. (2009). Vertical Handoff Decision Algorithms for Providing Optimized Performance in Heterogeneous Wireless Networks. IEEE Transactions on Vehicular Technology, 58(2), 865-881.

Li, S., Kim, J., Han, D., \& Lee, K. (2019). A Survey of Energy-Efficient Communication Protocols with QoS Guarantees in Wireless Multimedia Sensor Networks. Sensor, 19(1), 199.

Lin, J.-L., Hwang, K.-S., \& Huan, C.-Y. (2012). Active and Seamless Handover Control of MultiCamera Systems With 1-DoF Platforms. IEEE System Journal, 8(3), 769-777.

Liu, Q., Kwong, C., Zhang, S., \& Li, L. (2019). Fuzzy-TOPSIS Based Optimal Handover Decisionmaking Algorithm for Fifth-generation of Mobile Communications System. Journal of Communications, 14(10), 945-950. 
Naeem, B., Ngah, R., \& Hashim, S. (2018). Reduction in ping-pong effect in heterogeneous networks using fuzzy. Soft Computing, 23(1), 269-283.

Subramani, M., \& Kumaravelu, V. B. (2019). A Quality-Aware Fuzzy-Logic-Based Vertical Handover Decision Algorithm for Device-to-Device Communication. Arabian Journal for Science and Engineering, 44(3), 2413-2425.

Sun, M., \& Qian, H. (2016). Handover Management Scheme in SDN-based Wireless LAN. Journal of Communications, 11(3), 282-289.

Tillapart, P., Thumthawatworn, T., Viriyaphol, P., \& Santiprabhob, P. (2015). Intelligent handover decision based on fuzzy logic for heterogeneous wireless networks. 2015 12th International Conference on Electrical Engineering/Electronics, Computer, Telecommunications and Information Technology (ECTI-CON). Hua Hin, Thailand. 